\section{New Dehydrothymol Derivative from Iphiona mucronata*}

Mohamed Metwally

Department of Chemistry, Faculty of Science, University of Mansoura, Mansoura, Egypt

Z. Naturforsch. 40b, 1597-1598 (1985); received June 24, 1985

Dehydrothymol Derivative, Iphiona mucronata

A reinvestigation of Iphiona mucronata gave in addition to the known compound a new dehydrothymol derivative. Its structure was determined by spectroscopic methods.

\section{Introduction}

The genus Iphiona (Compositae, tribe Inuleae) is placed in the subtribe Inulinae [1]. The Inuleae include a selection of plants with medicinal activity [1]. In spite of the practical interest in plants of the Inuleae, the chemistry of the tribe has not been extensively explored [1]. In continuation to our study on the Egyptian Compositae we have now studied the constituents of Iphiona mucronata, and the results are discussed in this paper.

\section{Results and Discussion}

A reinvestigation of Iphiona mucronata afforded in addition to the known epoxythymol derivative $\mathbf{1}$, which isolated by us [2], a new dehydrothymol $\mathbf{2}$. The structure of $\mathbf{2}$ easily could be deduced from the spectral data. The molecular formula was $\mathrm{C}_{16} \mathrm{H}_{22} \mathrm{O}_{3}$, while the ${ }^{1} \mathrm{H}$ NMR spectrum $(400 \mathrm{MHz}, c f$. Experimental) indicated the presence of an isopropenyl group $2.03 \mathrm{t}$ $(3 \mathrm{H}, 5.11 \mathrm{dq}$ and $4.98 \mathrm{dq})$, a methoxy group at $\delta=$ 3.81 and a methyl group at $\delta=2.17$. The relative position of the different groups followed from the chemical shifts of the aromatic protons. Further evidence for structure $\mathbf{2}$ was gained from the IR and mass spectral data. The IR spectrum showed a clear and sharp band at $1740 \mathrm{~cm}^{-1}$ (CO ester) and $1630 \mathrm{~cm}^{-1}(\mathrm{C}=\mathrm{C})$. Compound 2 gave molecular ion $[\mathrm{M}]^{+}$at $\mathrm{m} / z 262$ corresponding to $\mathrm{C}_{16} \mathrm{H}_{22} \mathrm{O}_{3}$. The fragment $m / z 178$, produced from [M] ${ }^{+}$after removal of a ketene followed by ring closure and rearrangement. The base peak at $\mathrm{m} / z 59$ was obviously formed due to loss of $\mathrm{C}_{8} \mathrm{H}_{7} \mathrm{O}$ from the fragment $\mathrm{m} / z 178$ ( $c f$. Chart 1).

\footnotetext{
* Part 8 in the series of Egyptian Compositae, for part 7 , see M. A. Metwally, S. El-Dahmy, J. Jakupovic, F. Bohlmann, A. M. Dawidar, and S. A. Metwally, Phytochemistry (1985) in press.
}

Verlag der Zeitschrift für Naturforschung, D-7400 Tübingen 0340-5087/85/1100-1597/\$ 01.00/0

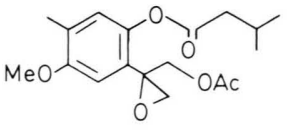

1
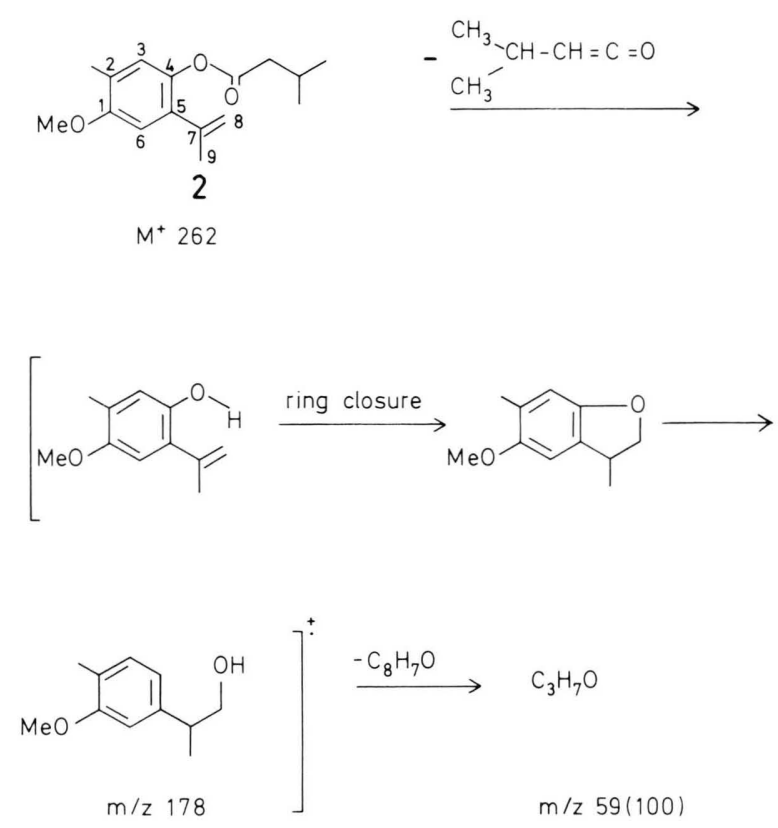

Chart 1

The structure of $\mathbf{1}$ was obtained from the ${ }^{1} \mathrm{H}$ NMR, MS and IR spectral data with authentic spectra.

Again the results on Iphiona do not show clear relationships to other genera, and highly oxygenated compounds seem to be characteristic for the genus but further investigation are needed.

\section{Experimental}

The air dried plant material, collected in March 1984, near Giza, Egypt, was extracted with ether, petroleum ether and methanol (1:1:1). The extract of the aerial parts $(150 \mathrm{~g})$ was first treated with methanol to remove long chain hydrocarbons and then partially separated by $\mathrm{CC}\left(\mathrm{SiO}_{2}\right)$ with petroleum ether and increasing amounts of ether and finally ether, methanol $(10: 1)$. The fraction obtained with $10 \%$ ether on repeated TLC (15\% ether) afforded $5 \mathrm{mg} \mathrm{2}$. The fraction obtained with $50 \%$ and $100 \%$ ether were combined and afforded $25 \mathrm{mg} \mathbf{1}$. 


\section{Dehydrothymol derivative (2)}

Colourless oil, IR $v_{\max }^{\mathrm{CCl}_{4}} \mathrm{~cm}^{-1} 1740$ (CO ester), and 1630 (C=C). MS $\mathrm{m} / \mathrm{z}$ (rel. int.): $262.156[\mathrm{M}]^{+}$(1) (calc. for $\left.\mathrm{C}_{16} \mathrm{H}_{22} \mathrm{O}_{3}: 262.156\right), 178$ [262-ketene ${ }^{+}$(5), $59\left[178-\mathrm{C}_{8} \mathrm{H}_{7} \mathrm{O}\right]^{+}(100) .{ }^{1} \mathrm{H} \mathrm{NMR}\left(\mathrm{CDCl}_{3}, 400 \mathrm{MHz}\right)$ $\delta: 6.67 \mathrm{~s}(\mathrm{H}-3), 6.76 \mathrm{~s}(\mathrm{H}-6), 5.11 \mathrm{dq}(\mathrm{H}-8, J[\mathrm{~Hz}]=1)$, 4.98 br s (H-8), 2.03 br s (H-9), 4-Oival (1.02 d,
$J[\mathrm{~Hz}]=7,2.36 \mathrm{~d}, J[\mathrm{~Hz}]=7$ and $2.21 \mathrm{~m}), 2.17$ $\mathrm{s}$ (Me-aromatic) and $3.81 \mathrm{~s}$ (OMe).

We thank Prof. Dr. A. Fayed, Department of Botany. Faculty of Science, Assiut University, Egypt, and Prof. Dr. F. Bohlmann, TU Berlin, West Germany, for the spectral measurements.
[1] H. Mexmüller, P. Leins, and H. Roessler, in V. H. Heywood, J. B. Harborne, and B. L. Turner (eds): The Biology and Chemistry of the Compositae, Academic Press, London 1977, p. 603, 604.
[2] M. A. Metwally, A. M. Dawidar, M. I. Youns, and S. A. Metwally, Indian J. Chem., in press (1985).

Nachdruck - auch auszugsweise - nur mit schriftlicher Genehmigung des Verlages gestattet Satz und Druck: Allgäuer Zeitungsverlag GmbH, Kempten 